\title{
PENGGUNAAN CITRA LANDSAT 8 DAN SISTEM INFORMASI GEOGRAFIS UNTUK ESTIMASI DEBIT PUNCAK DI DAERAH ALIRAN SUNGAI UNDA PROVINSI BALI
}

\author{
I Putu Sriartha \\ Jurusan Pendidikan Geografi, Universitas Pendidikan Ganesha \\ Singaraja, Indonesia \\ e-mail: psriartha@yahoo.com
}

\begin{abstract}
Abstrak
Penelitian ini dilakukan di Daerah Aliran Sungai Unda Provinsi Bali dengan tujuan: (1) mengkaji kemampuan teknik penginderaan jauh dalam ekstraksi data karakteristik lingkungan fisik DAS untuk estimasi debit puncak; (2) memperkirakan besarnya perubahan debit puncak dengan menggunakan Sistem Informasi Geografis. Data yang dikumpulkan melibatkan teknik penginderaan jauh untuk ekstraksi parameter-parameter fisik untuk menentukan tingkat pengaruh masing-masing parameter dalam perhitungan debit puncak. Hasil penelitian menunjukkan bahwa (1) Citra Landsat 8 Onboard Operational Land Imagery komposit 563 memperoleh akurasi sebesar 85,7\% dari interpretasi penutup lahan dan didukung data SRTM dapat digunakan untuk penentuan koefisien limpasan permukaan yang disusun dari overlay peta kemiringan lereng, peta penutup lahan, infiltrasi tanah dan timbunan air permukaan; (2) perhitungan debit puncak rerata dengan menggunakan metode rasional memberikan hasil sebesar $16,07 \mathrm{~m}^{3} /$ detik, sedangkan perhitungan debit puncak dari hasil pengukuran lapangan menggunakan metode manning memberikan hasil sebesar $20,01 \mathrm{~m}^{3} /$ detik. Mengacu pada hasil tersebut maka ketelitian yang diperoleh sebesar $80,31 \%$.
\end{abstract}

Kata kunci: Citra Landsat 8 OLI, Sistem Informasi Geografis, dan Debit Puncak

\begin{abstract}
This research was conducted in Unda Watershed with the aim of: (1) assess the ability of remote sensing techniques in data extraction watershed characteristics of the physical environment for the estimated peak discharge; (2) estimating peak discharge changes in Unda Watershed based on rational methods using Geographic Information System. The spatial data analysis involving remote sensing techniques for extracting physical parameters watershe. The results showed that (1) Landsat 8 Onboard Operational Land Imagerycomposite 563 obtained an accuracy of $85.7 \%$ of the land cover interpretation and backed the SRTM data can be used to determine the surface runoff coefficient composed of a slope maps, land cover maps, soil of infiltration and surface water piles; (2) The calculation of the average peak discharge using the rational method provides result of 16.07 $\mathrm{m} 3 / \mathrm{sec}$, while the peak discharge calculation of the results of field measurements using methods manning provide results of $20.01 \mathrm{~m} 3 / \mathrm{sec}$. Refers to these results the accuracy obtained amounted to $80.31 \%$.
\end{abstract}

Keywords: Landsat 8 Imagery, Geographic Information System, and peak discharge 


\section{PENDAHULUAN}

Daerah Aliran Sungai (DAS) merupakan suatu wilayah daratan yang menjadi kesatuan antara sungai dan anakanak sungainya yang dibatasi

oleh pemisah topografis yang berfungsi menampung air dari curah hujan, menyimpan dan mengalirkannya ke danau atau ke laut secara alami (Kepmen Pengelolaan DAS Terpadu, 2012). Perubahan penggunaan lahan dapat menimbulkan dampak terhadap peningkatan debit puncak aliran sebagai akibat tingginya aliran permukaan (runoff).Debit puncak merupakan suatu kondisi yang menunjukkan titik nilai debit tertinggi (maksimum) pada bagian hilir DAS atau Sub-DAS sebagai akibat dari meningkatnya aliran permukaan. Informasi perubahan debit puncak diperlukan untuk perencanaan pengendalian banjir dan pembuatan bangunan sipil teknis untuk pengendalian erosi.Metode empiris yang mendasarkan pada faktor-faktor fisiografi DAS dikembangkan untuk memudahkan estimasi debit puncak dengan memperhitungkan faktor koefisien aliran permukaan (C), intensitas hujan (I) dan luas daerah aliran sungai (DAS) (Sudaryatno, 2002).

Peningkatan jumlah dan kecepatan aliran permukaan, selain akibat hujan ekstrim juga oleh perubahan penggunaan lahan seperti lahan terbuka dan pemadatan tanah. Keterbukaan lahan menyebabkan jumlah dan intensitas hujan yang sampai di permukaan tanah meningkat, sedangkan pemadatan tanah menyebabkan berkurangnya kapasitas infiltrasi tanah sehingga jumlah dan aliran permukaan meningkat (Halengkara, 2011). Debit puncak terjadi ketika seluruh aliran permukaan yang berada di daerah aliran sungai (DAS) mencapai titik outlet (bagian hilir suatu DAS atau Sub-DAS sebagai tempat berkumpulnya seluruh aliran permukaan yang mengalir dari bagian hulu DAS). Faktor utama yang mempengaruhi besarnya debit puncak yaitu karakteristik hujan dan karakteristik DAS (Asdak,2002).

Ketersediaan data terkait parameter fisik DAS masih sangat terbatas sehingga perlu alternatif untuk memperoleh data tersebut. Teknologi penginderaan jauh merupakan teknik yang banyak digunakan untuk menyediakan data dan informasi geografis secara cepat dan akurat. Data tentang faktor-faktor fisiografi DAS dapat diekstraksi dengan menggunakan teknologi penginderaan jauh. Lillesand, et al.(2004) menyatakan bahwa teknologi penginderaan jauh belum dimanfaatkan secara optimal terutama dalam kajian hidrologi (DAS), padahal penginderaan jauh mempunyai keunggulan untuk ekstraksi parameterparameter lahan dengan mudah, cepat, mencakup daerah yang luas, serta mampu menyajikan data hidrologi secara keruangan (spatial variability).

Berdasarkan permasalahan tersebut, perlu dilakukan pemantauan debit puncak secara cepat dengan memanfaatkan Citra Landsat 8 OLI perekaman April 2014 yang diintegrasikan dengan sistem informasi geografis. Tujuan utama dari penelitian ini adalah mengkaji kemampuan teknik penginderaan jauh dalam ekstraksi data karakteristik lingkungan fisik DAS untuk estimasi debit puncak, dan memperkirakan besarnya perubahan debit puncak pada DAS Unda berdasarkan metode rasional dengan menggunakan sistem informasi geografis.

\section{METODE}

Penelitian ini dilakukan pada bulan Juni 2014 di DAS Unda yang mencakup 
sebagian wilayah Kabupaten Karangasem dan Kabupaten Klungkung Provinsi Bali, yang terletak pada 8 ${ }^{\circ} 34^{\prime} 02^{\prime \prime}$ LS - 8 $17^{\prime} 03^{\prime \prime}$ LS dan $115^{\circ} 23^{\prime} 05^{\prime \prime}$ BT - $115^{\circ} 31^{\prime} 01^{\prime \prime}$ BT dengan luas $215,6 \mathrm{~km}^{2}$.

Data yang diperlukan untuk analisis debit puncak DAS Unda meliputi Peta Kemiringan Lereng dari Citra Shuttle Radar Topography Mission (SRTM), Peta Penutup Lahan dari Citra Landsat 8 OLI (Onboard Operational Land Imagery) serta data pengukuran lapangan tentang infiltrasi tanah, timbunan air permukaan dan intensitas hujan harian puncak. Integrasi penginderaan jauh dan SIG dilakukan melalui software ENVI 4.5 (digunakan untuk klasifikasi multispektral) dan Arc GIS 10.1 dengan extension spatial analyst (untuk mengolah data) sehingga menghasilkan informasi spasial yang baru.

Perhitungan koefisien limpasan permukaan (nilai C) bertujuan untuk menentukan tingkat pengaruh keseluruhan parameter fisik DAS terhadap estimasi debit puncak. Semakin tinggi harkat setiap parameter fisik DAS serta luas satuan medan maka koefisien limpasan permukaan yang ditimbulkan akan semakin tinggi pula sehingga berpengaruh pada debit puncak yang semakin meningkat. Koefisien limpasan permukaan dapat dihitung berdasarkan karakteristik fisik DAS (relief/kemiringan lereng, tutupan lahan, infiltrasi tanah dantimbunan air permukaan) (Wibowo, 2008). Mengacu pada pendapat Wibowo tersebut, maka paramater lingkungan fisik DAS yang digunakan untuk menentukan nilai $\mathrm{C}$ adalah kemiringan lereng, kerapatan aliran, infiltrasi tanah, dan vegetasi penutup. Kemiringan lereng dimodelkan melalui digital elevation model (DEM). Timbunan air permukaan didekati melalui variasi kerapatan aliran. Infiltrasi tanah dideteksi dari bentuklahan, tutupan lahan, dan tekstur tanah. Vegetasi penutup diperoleh melalui klasifikasi multispektral citra.

Nilai C merupakan hasil overlay dari keempat parameter, sedangakn untuk memperoleh nilai $\mathrm{C}$ total perlu melakukan perkalian antara harkat total hasil overlay dengan faktor pembobot setiap satuan medan.Pada dasarnya penyusunan model ini adalah simulasi nilai koefisien limpasan permukaan secara spasial dengan metode Cook. Overlay dilakukan dengan teknik penjumlahan harkat masing-masing parameter. Berikut ini merupakan formulasi untuk menentukan nilai dari $\mathrm{C}$ total.

\section{C total $=\sum$ skor pada tiap satuan medan (harkat total) $\mathrm{x}$ faktor pembobot.

Formula tersebut memiliki ketentuan: (1) skor pada tiap satuan medan dihitung dengan penjumlahan harkat dari parameterparameter: kerapatan aliran, kemiringan lereng, vegetasi penutup dan infiltrasi tanah. (2) Faktor pembobot adalah luas satuan medan dibagi dengan luas DAS keseluruhan.

Tabel 1. Klasifikasi Koefisien Limpasan Permukaan

\begin{tabular}{lc}
\hline \multicolumn{1}{c}{ Klasifikasi } & Harkat Total \\
\hline Kelas I (Rendah) & $0-25$ \\
Kelas II (Normal) & $25-50$ \\
Kelas III (Tinggi) & $50-75$ \\
Kelas IV (Ekstrim) & $>75$ \\
\hline Sumber: Chow (1964) dalam Sudaryatno (2000)
\end{tabular}


Peta kemirirngan lereng ditentukan berdasarkan data SRTM yang diinterpolasi menggunakan tool slope untuk mengidentifikasi gradient kemiringan lereng. Klasifikasi kemiringan lereng didasarkan pada kriteria Cook (Sudaryatno, 2000).

Penutup lahan ditentukan berdasarkan klasifikasi berbasis piksel menggunakan saluran multispektral pada Citra Landsat 8 komposit 563 (false color) dengan pertimbangan bahwa saluran tersebut mampu membedakan objek daratan yang lebih baik berdasarkan nilai spektral yang dipantulkan (Mather, 1987). Klasifikasi tutupan lahan menggunakan kriteria Meijerink (1970, dalam Sudaryatno, 2000).

Analisis timbunan air permukaan dilakukan dengan mengetahui kerapatan alirannya berdasarkan pada kerapatan aliran (Dd) dari Linsley (1959) disesuaikan dengan metode Cook (rumus 2).

$$
\text { Dd }=\frac{\mathbf{L}}{\mathbf{A}}
$$

Keterangan :

$\mathrm{Dd}=$ kepadatan aliran $\left(\mathrm{km} / \mathrm{km}^{2}\right)$

$\mathrm{L}=$ jumlah panjang alur sungai $(\mathrm{km})$

$A=$ luas DAS $\left(\mathrm{km}^{2}\right)$.

Klasifikasi kerapatan aliran terhadap timbunan air permukakan didasarkan pada penyesuaian kriteria Cook dan kriteria Lindsley (Sudaryatno, 2000).

Perhitungan intensitas hujan harian puncak ini dilakukan untuk menghitung debit puncak dengan teknik penginderaan jauh menggunakan formula Monobone dalam Sosrodarsono(1983) yang dikutip dari Yulius (2014), yaitu:

$$
I=\left(\frac{P}{24}\right)\left(\frac{24}{t}\right)^{2 / 3}
$$

Keterangan :

$\mathrm{I}$ = intensitas hujan ( $\mathrm{mm} / \mathrm{jam})$

$\mathrm{P}=$ hujanharian $(\mathrm{mm})$

$\mathrm{t}=$ periode hujan yang besarnya $=$ waktu konsentrasi Tc (jam)

Metode untuk pengukuran debit puncak menggunakan metode rasional yang mempertimbangkan adanya hujan yang merata di seluruh DAS dan durasi hujan sama dengan waktu konsentrasi (Tc), dirumuskan sebagai berikut:

$Q p=0,278 \mathrm{Cp}$. I . A

Keterangan :

$\mathrm{Qp}=$ debit puncak ( $\mathrm{m}^{3} /$ detik)

$\mathrm{Cp}=$ keofisien limpasan permukaan (\%) sasat kejadian hujan

I = intensitas curah hujan ( $\mathrm{mm} / \mathrm{jam})$ lamanya sama dengan waktu konsentrasi $\left(T_{c}\right)$

A = luas DAS $\left(\mathrm{km}^{2}\right)$

$0,278=$ koefisien untuk penyesuaian dalam metrik

Sebagai pembanding hasil pengukuran metode rasional, maka dilakukan pengukuran dengan metode Manning, seperti pada rumus (5).

Qmaks= V.A.

$$
=1 / n \cdot R^{2 / 3} \cdot S^{1 / 2} \cdot A
$$

Dimana $R=A / P$

$$
\mathrm{V}=\mathrm{Q} / \mathrm{A}
$$

$\mathrm{Tc}=\mathrm{L} /(60 \mathrm{~V})$

Keterangan:

$\mathrm{Q}=$ Debit aliran $\left(\mathrm{m}^{3} / \mathrm{s}\right)$

$\mathrm{V}=$ Kecepatanaliran $(\mathrm{m} / \mathrm{s})$

$R=$ Jari-jarihidraulik $(A / P)(m)$

$A=$ Luaspenampangbasah $\left(\mathrm{m}^{2}\right)$ 
$\mathrm{P}=$ Kelilingpenampangbasah $(\mathrm{m})$

$\mathrm{S}=$ Kemiringandasarsaluran $(\mathrm{m} / \mathrm{m})$

$\mathrm{n}=$ koefisien manning $=\mathrm{n} 0+\mathrm{n} 1+\mathrm{n} 2+. \mathrm{n} 5$

$\mathrm{L}=$ panjangpengaliran $(\mathrm{m})$

$\mathrm{Tc}=$ waktukonsentrasi(menit)

\section{HASIL DAN PEMBAHASAN}

Untuk menjelaskan karakteristik lingkungan fisik DAS dan memudahkan proses perhitungan debit puncak, maka daerah penelitian dibagi menjadi 5 sub-DAS utama berdasarkan batas fisik berupa igir yang nampak dari hasil interpretasi citra satelit, serta dengan melihat shapefile aliran sungai yang kemudian dideliniasi untuk mengelompokkan menjadi sub-DAS. Pembagian sub-DAS dapat dilihat pada Peta Batas sub-DAS Unda (Gambar 1), sementara luasnya pada Tabel 2.

Tabel 2. Luas Masing-Masing sub-DAS

\begin{tabular}{crr}
\hline Sub-DAS & Luas $\mathbf{( K m}^{\mathbf{2}}$ ) & Persentase $\mathbf{~ \% )}$ \\
\hline Sub-DAS 1 & 67 & 31,08 \\
Sub-DAS 2 & 44,3 & 20,54 \\
Sub-DAS 3 & 23 & 10,67 \\
Sub-DAS 4 & 39 & 18,09 \\
Sub-DAS 5 & 42,3 & 19,62 \\
\hline Total & 215,6 & 100 \\
\hline
\end{tabular}

Sumber: Hasil Pengolahan Data, 2014

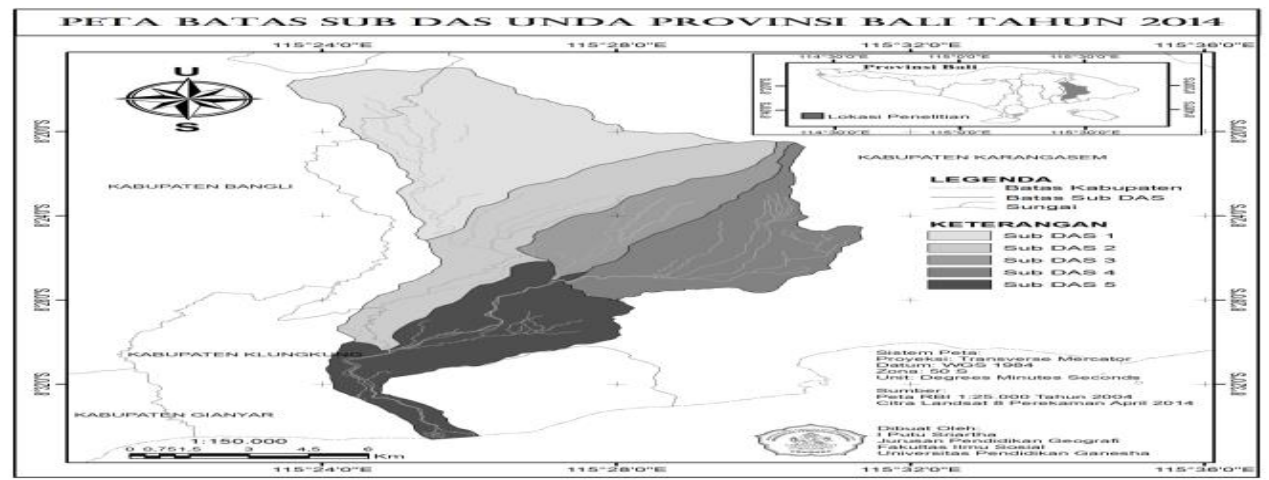

Gambar 1. Peta Batas sub-DAS Unda

Hasil analisis kemiringan lereng menunjukkan bahwa kemiringan lereng DAS Unda cukup bervariasi seperti terlihat pada Gambar 2. Kelas lereng III (agak curam) kemiringan lereng 10-30\% mendominasi DAS Unda dengan luasan mencapai $117,82 \mathrm{~km}^{2}$ atau sebesar $54,79 \%$ dari luas DAS, sedangakan kelas lereng I (datar) kemiringan $0-5 \%$ merupakan luasan terkecil yaitu hanya 13,18 atau sebesar $6,13 \%$. 


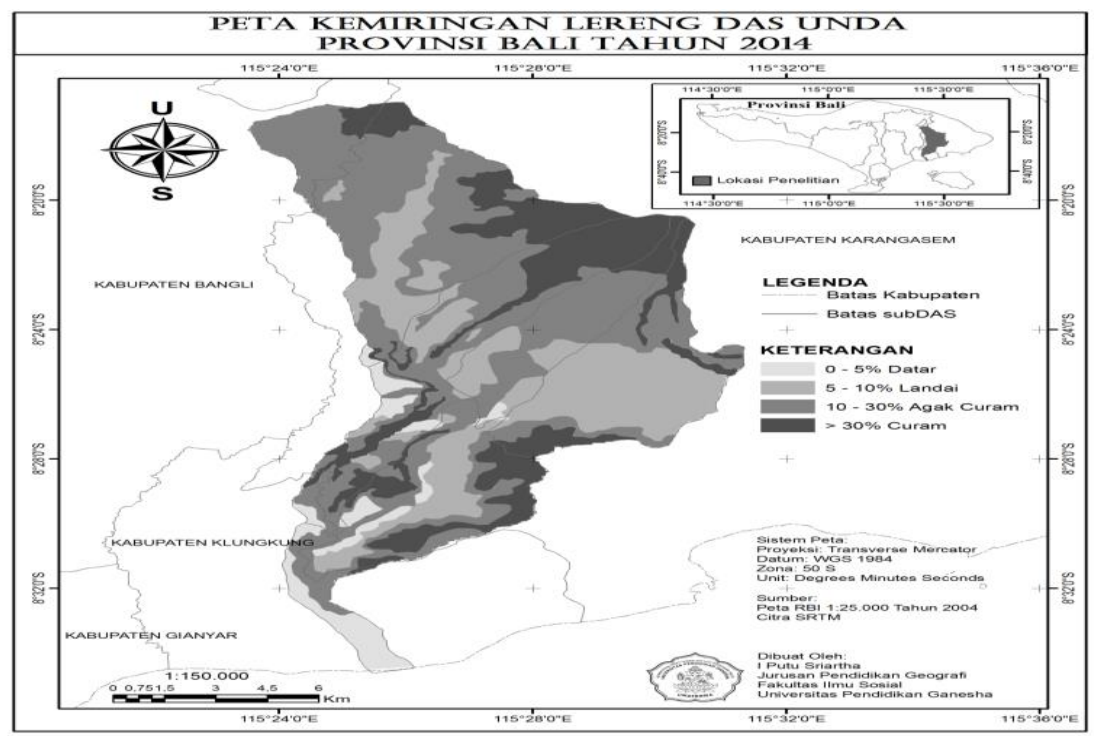

Gambar 2. Peta Kemiringan Lereng DAS Unda

$\begin{array}{ccc}\text { Dengan } & \text { demikian, secara } \\ \text { keseluruhan DAS Unda memiliki }\end{array}$ karakteristik agak curam yaitu kelas lereng III dengan kemiringan $10-30 \%$ sehingga berpengaruh pada semakin meningkatnya koefisien limpasan permukaan.

Penutup lahan merupakan salah satu faktor yang berpengaruh terhadap terjadinya aliran permukaan. Perubahan penutup lahan menyebabkan adanya perubahan kondisi debit banjir DAS. Penutup Iahan diklasifikan menjadi beberapa objek, diantaranya adalah awan, bayangan awan, hutan kerapatan tinggi, hutan kerapatan rendah, jalan, permukiman, sawah, tubuh air (sungai), lahan terbuka dan tak terklasifikasi (daerah volkan).

Berdasarkan hasil interpretasi Citra Landsat 8 diperoleh akurasi sebesar 85,7\% sehingga dapat dijadikan sumber data untuk analisis selanjutnya. Variasi spasial penutup lahan DAS Unda dapat dilihat pada gambar 3. 


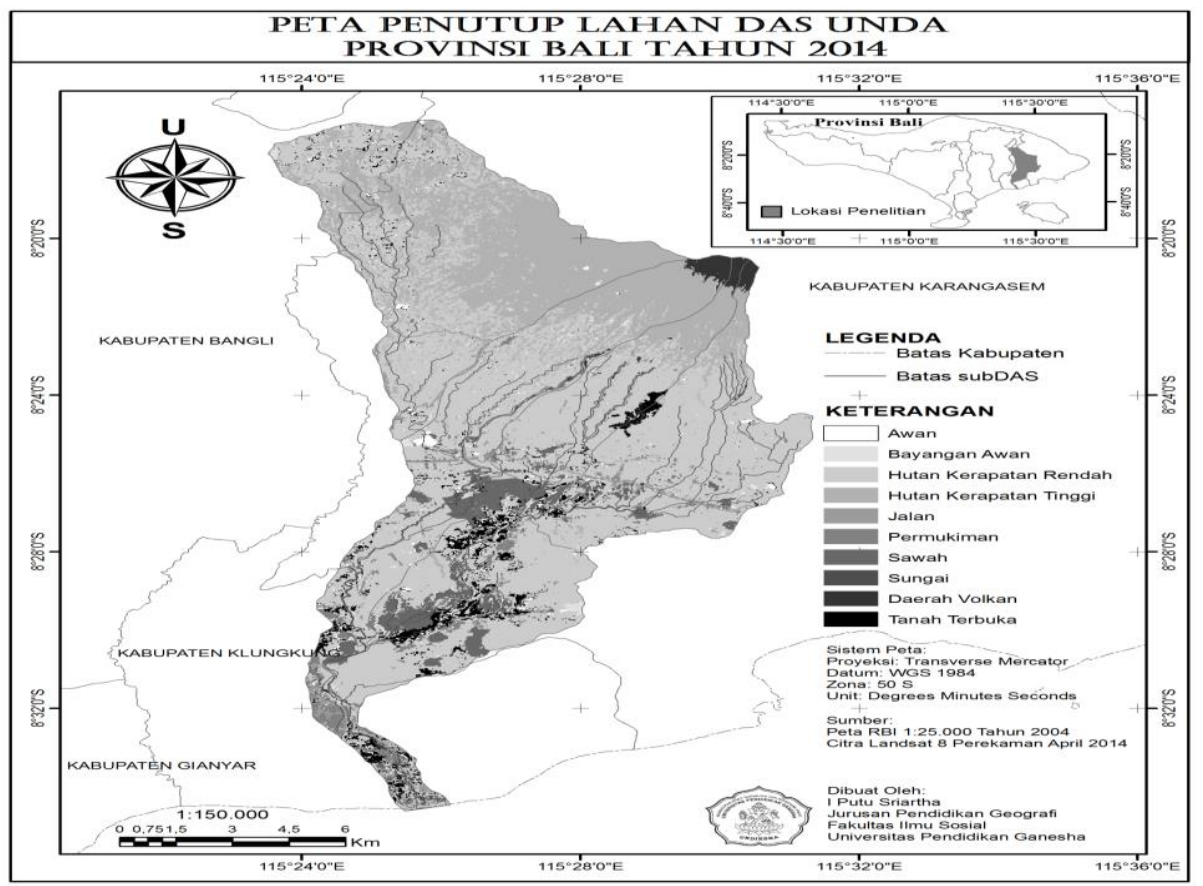

Gambar 3. Peta Penutup Lahan DAS Unda

Berdasarkan Gambar 3 dapat dikemukakan bahwa penutup lahan DAS Unda didominasi dengan hutan kerapatan tinggi dan hutan kerapatan rendah.Hal tersebut sesuai dengan karakteristik kemiringan lereng DAS yang terkategori agak curam sehingga daerah tersebut menjadi kawasan konservasi hutan. Karakteristik untuk masing-masing subDAS, yaitu pada sub-DAS 1 didominasi oleh hutan kerapatan tinggi dengan luas mencapai $33,5 \mathrm{~km}^{2}$. Penutup lahan subDAS 2 didominasi oleh hutan kerapatan rendah dengan luas mencapai $20,4 \mathrm{~km}^{2}$. Sub-DAS 3 memiliki penutup lahan hutan kerapatan rendah yaitu $12,7 \mathrm{~km}^{2}$, dan paling sediit dijumpai adalah permukiman hanya $0,2 \mathrm{~km}^{2}$, sedangkan pada sub-DAS 4 memliki penutup lahan paling kecil adalah lahan terbuka dengan luas $0,4 \mathrm{~km}^{2}$, namun hutan kerapatan rendah masih mendominasi pada sub-DAS ini, yaitu dengan luas mencapai $27,7 \mathrm{~km}^{2}$. Tidak jauh berbeda dengan sub-DAS sebelumnya, penutup lahan pada sub-DAS 5 didominasi oleh hutan kerapatan rendah yaitu 20,1 $\mathrm{km}^{2}$, namun keberadaan hutan kerapatan tinggi sudah hampir tidak dijumpai yaitu hanya $0,1 \mathrm{~km}^{2}$. Justru keberadaan sawah yang semakin meningkat luasannya yaitu $15,8 \mathrm{~km}^{2}$, hal ini mengindikasikan bahwa dengan kemiringan lereng datar hingga landai dimanfaatkan oleh masyarakat untuk mengembangkan usaha pertanian khususnya sawah sekaligus sebagai tempat bermukim.

Infiltrasi yang dimaksud dalam penelitian ini adalah infiltrasi vertikal, yaitu proses masuknya air ke dalam tanah melalui permukaan tanah. Faktor infiltrasi tanah di dekati dengan menggunakan data dan informasi jenis tanah yang ada pada 
DAS Unda, dengan dasar pemahaman bahwa setiap jenis tanah memiliki karakteristik tersendiri terhadap kemampuan infiltrasi airnya. Berdasarkan jenis tanah dan teksturnya maka dapat ditentukan tingkat infiltrasi pada masingmasing Sub-DAS berdasarkan klasifikasi dari metode Cook.

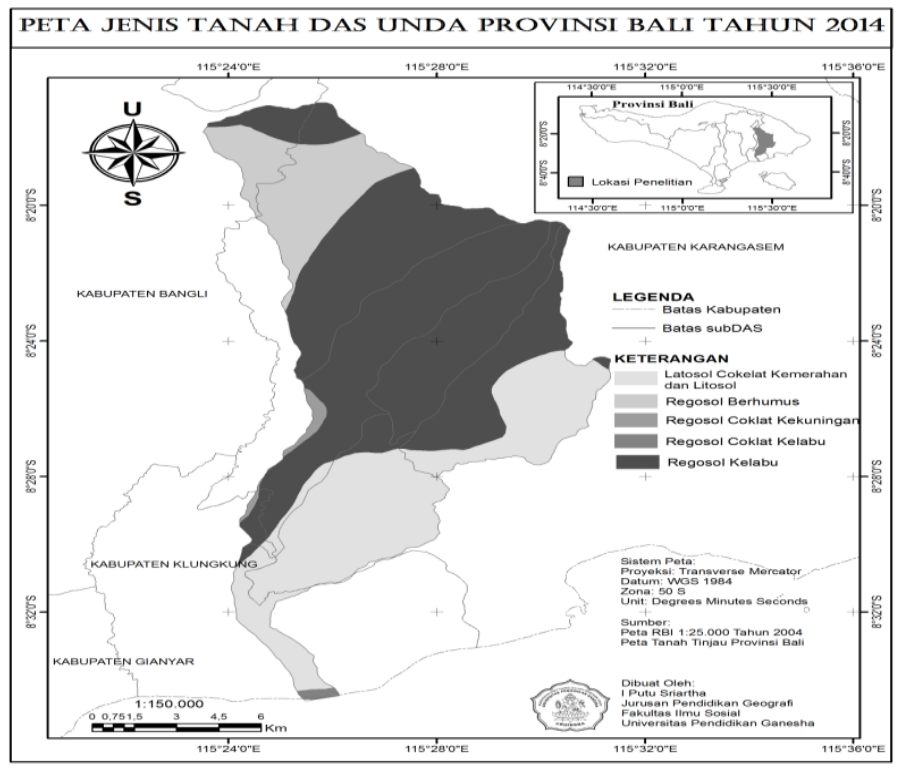

Gambar 4. Peta Jenis Tanah DAS Unda

Hasil penelitian tentang jenis tanah yang terdapat di DAS Unda secara visual dapat dilihat pada Peta Jenis Tanah DAS Unda (Gambar 4).Berdasarkan Gambar 4 dapat dikemukakan bahwa jenis tanah regosol kelabu dengan tekstur pasir bergeluh terdapat diseluruh bagian DAS Unda dengan luas mencapai $111,113 \mathrm{Km}^{2}$ atau mencakup $45,8 \%$ luasan DAS.

Jenis tanah regosol berhumus dengan tekstur pasir bergeluh dapat ditemui pada sub DAS I dan II, mencakup luasan $66,113 \mathrm{Km}^{2}$ atau $27,50 \%$ dari seluruh DAS Unda. Sementara jenis tanah latosol coklat kemerahan dan litosol dengan tekstur lempungan dan tingkat infiltrasi lambat, mencakup sub DAS II, IV dan V seluas $61,82 \mathrm{Km}^{2}$ atau $25,52 \%$ dari luasan DAS
Unda. Sementara jenis tanah lainnya adalah regosol coklat kekuningan dan regosol coklat kelabu dengan luasan tidak lebih dari $3 \mathrm{Km}^{2}$.

Informasi mengenai kerapatan aliran diperlukan untuk mengetahui timbunan air permukaan. Klasifikasi kerapatan aliran (Dd) digunakan untuk melakukan analisis tumbunan air permukaan.Berdasarkan hasil pengolahan data, dapat dikemukakan bahwa Sub-DAS 1 diperoleh perhitungan luas area sebesar $67 \mathrm{~km}^{2}$, panjang sungai $251.4 \mathrm{~km}$, dan didapatkan kerapatan aliran sebesar $3.8 \mathrm{~km} / \mathrm{km}^{2}$. Sub-DAS 2 memiliki luas area sebesar $44 \mathrm{~km}^{2}$, panjang sungai $163.2 \mathrm{~km}$, kerapatan alirannya adalah 3.7 $\mathrm{km} / \mathrm{km}^{2}$. Sub-DAS 3 luas areanya sebesar $23 \mathrm{~km}^{2}$ dan panjang alur sungainya adalah 
$87.8 \mathrm{~km}$, kerapatan alirannya adalah 3.9 $\mathrm{km} / \mathrm{km}^{2}$. Sub-DAS 4 memiliki luas area sebesar $39 \mathrm{~km}^{2}$, dan panjang aliran sungainya adalah 124.9 km, kerapatan alirannya adalah $3.2 \mathrm{~km} / \mathrm{km}^{2}$. Kerapatan aliran setiap sub-DAS dapat dilihat pada tabel berikut:

Tabel 3. Kerapatan Aliran Masing-Masing Sub-DAS

\begin{tabular}{crrrr}
\hline Sub-DAS 1 & Sub-DAS 2 & Sub-DAS 3 & Sub-DAS 4 & Sub-DAS 5 \\
\hline 3,7527 & 3,7097 & 3,8145 & 3,2017 & 3,4180 \\
\hline Sumber: Hasil Pengolahan Data, 2014 & &
\end{tabular}

\section{Koefisien Limpasan Permukaan}

Paramater yang digunakan dalam lingkungan fisik DAS untuk menentukan nilai $\mathrm{C}$ adalah kemiringan lereng, kerapatan aliran, infiltrasi tanah, dan vegetasi penutup. Nilai $\mathrm{C}$ total merupakan hasil overlay dari keempat parameter yang dikalikan dengan faktor pembobot. Untuk lebih jelasnya dapat dilihat pada formulasi berikut ini.

\section{C total $=\sum$ skor pada tiap satuan medan $x$ faktor pembobot}

Formula yang digunakan tersebut memiliki ketentuan sebagai berikut:

1. Skor pada tiap satuan medan dihitung dengan penjumlahan harkat dari parameter-parameter: kerapatan aliran, kemiringan lereng, vegetasi penutup dan infiltrasi tanah.

2. Faktor pembobot adalah luas satuan medan dibagi dengan luas DAS keseluruhan.

Tabel 4. Hasil Perhitungan C Total Pada Salah Satu Satuan Lahan

\begin{tabular}{|c|c|c|c|c|}
\hline Parameter & Nama kelas/nilai & Skor & $\begin{array}{l}\text { Luas Sub- } \\
\text { DAS } \\
\left(\mathrm{km}^{2}\right)\end{array}$ & $\begin{array}{l}\text { Luas Satuan medan } \\
\qquad\left(\mathbf{k m}^{2}\right)\end{array}$ \\
\hline $\begin{array}{l}\text { Penutup } \\
\text { vegetasi }\end{array}$ & $\begin{array}{c}\text { Hutan kerapatan } \\
\text { tinggi } \\
\text { Latosol coklat }\end{array}$ & 5 & 43.4967 & 0.0009 \\
\hline Jenis tanah & $\begin{array}{l}\text { kemerahan dan } \\
\text { litosol }\end{array}$ & 15 & 43.4967 & 0.0009 \\
\hline Kerapatan aliran & 3.42 & 15 & 43.4967 & 0.0009 \\
\hline $\begin{array}{l}\text { Kemiringan } \\
\text { lereng }\end{array}$ & $>30$ & 40 & 43.4967 & 0.0009 \\
\hline & Skor total & 75 & $\begin{array}{c}\text { Faktor } \\
\text { Pembobot }\end{array}$ & 48828.8889 \\
\hline & C & $\begin{array}{r}0.000 \\
01551 \\
843\end{array}$ & & \\
\hline
\end{tabular}

Sumber: Hasil Pengolahan Data, 2014 
Tabel 5. Hasil analisis curah hujan maksimum rata-rata setiap sub-DAS

\begin{tabular}{|c|c|c|c|c|c|}
\hline sub-DAS & h1-h2 & $L$ (meter) & R 24 & tc menit & $\mathrm{I}(\mathrm{mm} / \mathrm{jam})$ \\
\hline sub-DAS 1 & 1475 & 14000 & 39.47048 & 0.11030 & 59.49491 \\
\hline sub-DAS 2 & 2550 & 20500 & 34.25389 & 0.09706 & 56.22637 \\
\hline sub-DAS 3 & 2138 & 13500 & 35.55634 & 0.08059 & 66.06776 \\
\hline sub-DAS 4 & 2137 & 12800 & 30.81158 & 0.07738 & 58.82371 \\
\hline
\end{tabular}

Dari hasil perbandingan curah hujan harian daerah di DAS Unda yang dibagi per sub-DAS diperoleh bahwa curah hujan harian paling tinggi terdapat pada sub-DAS 1 sebesar 39.47048 (mm/hari) dengan waktu konsentrasi selama 0.11030 sehingga menghasilkan intensitas curah hujan sebesar 59.49491 (mm/jam) dan paling rendah berada pada sub-DAS 4 sebesar $30.81158(\mathrm{~mm} /$ hari) dengan waktu konsentrasi selama 0.07738 sehingga menghasilkan intensitas curah hujan sebesar 58.82371 ( $\mathrm{mm} / \mathrm{jam})$

\section{Debit Puncak DAS Unda}

Perhitungan debit puncak pada DAS Unda dengan metode rasional disajikan dalam tabel sebagai berikut:

Tabel 6. Perhitungan Debit Puncak dengan Metode Rasional

\begin{tabular}{cccccc}
\hline Nama Sub-DAS & C & I & A & Koefisien & Qp \\
\hline Sub-DAS 1 & 0.58519 & 0.6071 & 66.87 & 0.278 & 6.60505041 \\
Sub-DAS 2 & 0.63331 & 0.3059 & 43.57 & 0.278 & 2.34679486 \\
Sub-DAS 3 & 0.66655 & 0.4576 & 22.60 & 0.278 & 1.91729125 \\
Sub-DAS 4 & 0.61452 & 0.4131 & 39.09 & 0.278 & 2.75985879 \\
Sub-DAS 5 & 0.70647 & 0.2902 & 43.49 & 0.278 & 2.4792266 \\
\hline
\end{tabular}

Sumber: Hasil Perhitungan, 2014 
Hasil perhitungan debit puncak di Sub-DAS 1 didapatkan nilai $\mathrm{Qp}$ sebesar $6.60505041 \mathrm{~m}^{3} /$ detik. Besarnya nilai Qp di sub-DAS 1 dipengaruhi oleh luas area yang besar sehingga daya tampung air hujan akan besar pula. Penutup lahan didominasi hutan kerapatan rendah hingga tinggi $(58,2$ $\mathrm{km}^{2}$ )sehingga nilai koefisien limpasan lebih kecil. Pada Sub-DAS 2 penutup lahan bervegetasi tegakan mulai berkurang, terdapat lahan pertanian (sawah) sehingga saat terjadi hujan laju air hujan (limpasan permukaan) menjadi lebih besar. Selain itu intensitas hujan termasuk kecil sehingga didapatkan nilai Qp sebesar 2.34679486 $\mathrm{m}^{3} /$ detik.

Sub-DAS 3 mempunyai luas area terkecil di DAS Unda. Penutup lahan bervegetasi tegakan (hutan kerapatan tinggi dan hutan kerapatan rendah) mulai berkurang, terdapat sawah dan lahan terbuka. Air hujan yang jatuh menjadi runoff karena beberapa faktor di atas. Banyaknya limpasan permukaan yang terjadi maka nilai Qp sebesar 1.91729125 $\mathrm{m}^{3} /$ detik, nilai ini lebih kecil dari 2 Sub-DAS sebelumnya. Namun, nilai intensitas hujan sedikit lebih besar dariSub-DAS 2 dengan selisih sebesar $0.151745215 \mathrm{~mm} /$ hari.
Nilai Qp Sub-DAS 4 terkecil kedua setelah nilai Qp Sub-DAS 1, Sub-DAS 4 penutup lahan hutan kerapatan tinggi sedikit berkurang namun hutan kerapatan rendah lebih banyak $\left(28,7 \mathrm{~km}^{2}\right)$, selain itu terdapat permukiman dan sawah $\left(4,8 \mathrm{~km}^{2}\right)$ sehingga limpasan permukaan saat terjadi hujan tidak terlalu besar karena terdapat vegetasi, maka dari hasil perhitungan didapatkan nilai Qp sebesar 2.75985879 $\mathrm{m}^{3} /$ detik.Pada Sub-DAS 5 nilai koefisien limpasan permukaan merupakan nilai terbesar, karena penutup lahan hutan kerapatan rendah hingga tinggi lebih sedikit $\left(9,2 \mathrm{~km}^{2}\right)$, penutup lahan permukiman dan sawah meningkat $\left(17,3 \mathrm{~km}^{2}\right)$, saat hujan terjadi air permukaan yang mengalir cenderung lebih besar. Hal ini selanjutnya akan menyebabkan nilai $Q p$ sebesar $2.4792266 \mathrm{~m}^{3} /$ detik.

Untuk mengetahui tingkat akurasi metode rasional, maka dilakukan juga pengukuran debit puncak di lapangan dengan metode Manning. Pengukuran dilaksanakan pada 4 (empat) titik lokasi yang merupakan outlet masing-masing subDAS. Hasilnya dapat dilihat pada Tabel 7.

Perbandingan nilai hasil perhitungan debit puncak dengan metode rasional dan metode manning dapat dilihat pada Tabel 8.

Tabel 7.Perhitungan Debit Puncak Dengan Metode Manning

\begin{tabular}{|c|c|c|c|c|c|c|}
\hline $\begin{array}{l}\text { Sub } \\
\text { DAS }\end{array}$ & $\begin{array}{c}\text { Nilai } \\
\text { Kekasaran } \\
\text { Manning } \\
\text { (n) }\end{array}$ & $\begin{array}{l}\text { Slope } \\
(\mathrm{m} / \mathrm{m})\end{array}$ & $\begin{array}{c}\text { Luas } \\
\text { Penampa } \\
\text { ng }\left(\mathrm{m}^{2}\right)\end{array}$ & $\begin{array}{c}\text { Jari Hidr } \\
\text { aulik (A) } \\
\text { P) }\end{array}$ & $\begin{array}{l}\text { Kecepatan } \\
\text { (V) (m/dtk) }\end{array}$ & $\begin{array}{c}\text { Debit } \\
\text { Puncak } \\
\text { (Qp) (m³ } \\
\text { dtk) }\end{array}$ \\
\hline Sub DAS 1 & 0,043 & 0,077 & 1,7400 & 0,371 & 3,325 & 5,785 \\
\hline Sub DAS 2 & 0,033 & 0,086 & 1,5500 & 0,299 & 3,969 & 6,153 \\
\hline Sub DAS 3 & 0,03 & 0,069 & 1,5000 & 0,396 & 1,709 & 3,772 \\
\hline Sub DAS 4 & 0,025 & 0,0874 & 1,3600 & 0,661 & 3,199 & 4,515 \\
\hline
\end{tabular}

Sumber: Hasil Perhitungan, 2014 
Tabel 8. Perbandingan Nilai Debit Puncak \& Akurasi Perhitungan

\begin{tabular}{|c|c|c|c|c|}
\hline $\begin{array}{l}\text { Nama Sub- } \\
\text { DAS }\end{array}$ & $\begin{array}{l}\text { Qp Metode Rasi } \\
\text { onal (m } 3 / \mathrm{dtk})\end{array}$ & $\begin{array}{c}\text { Qp Metode } \\
\left.\text { Manning( } \mathrm{m}^{3} / \mathrm{dtk}\right)\end{array}$ & $\begin{array}{l}\text { Akurasi Hasil } \\
\text { Estimasi (\%) }\end{array}$ & $\begin{array}{c}\text { Keterang } \\
\text { an }\end{array}$ \\
\hline Sub-DAS 1 & 6,605 & 5,785 & $114,17 \%$ & Over $14 \%$ \\
\hline Sub-DAS 2 & 2,346 & 6,153 & $38,1 \%$ & \\
\hline Sub-DAS 3 & 1,917 & 3,772 & $50,6 \%$ & \\
\hline Sub-DAS 4 & 2,759 & 4,515 & $60,9 \%$ & \\
\hline Sub-DAS 5 & $\begin{array}{l}2,479 \\
\text { ata-Rata Persentas }\end{array}$ & Akurasi & $80,31 \%$ & \\
\hline
\end{tabular}

Sumber: Hasil Perhitungan, 2014

Berdasarkan Tabel 8 dapat dikemukakan bahwa pada Sub-DAS I dengan luas $66,8 \mathrm{~km}^{2}$ hasil perhitungan dengan metode rasional menghasilkan nilai debit puncak sebesar 6,605 $\mathrm{m}^{3} /$ detik, sedangkan hasil pengukuran di lapangan diperoleh estimasi debit puncak sebesar $5,785 \mathrm{~m}^{3} /$ detik. Artinya akurasi perhitungan dengan menggunakan metode rasional menghasilkan nilai yang melebihi nilai hasil pengukuran lapangan sebesar 14\%. SubDAS II dengan luas 43,5 $\mathrm{km}^{2} \mathrm{hasil}$ perhitungan dengan metode rasional menghasilkan nilai debit puncak sebesar 2,346 $\mathrm{m}^{3} /$ detik, sedangkan hasil pengukuran di lapangan diperoleh estimasi debit puncak sebesar 6,153 $\mathrm{m}^{3} /$ detik. Pada sub-DAS II ini tingkat akurasi hasil perhitungan debit puncak metode rasional hanya $38,1 \%$.

Pada Sub-DAS III dengan luas $22,6 \mathrm{~km}^{2}$ hasil perhitungan dengan metode rasional menghasilkan nilai debit puncak sebesar 1,917 $\mathrm{m}^{3} /$ detik, sedangkan hasil pengukuran di lapangan diperoleh estimasi debit puncak sebesar 3,772 $\mathrm{m}^{3} /$ detik sehingga akurasi metode rasional dibandingkan dengan hasil pengukuran di lapangan sebesar50,6\%. Sub-DAS IV dengan luas $39 \mathrm{~km}^{2}$ hasil perhitungan metode rasional menghasilkan nilai debit puncak sebesar 2,759 $\mathrm{m}^{3} /$ detik, sedangkan hasil pengukuran di lapangan diperoleh estimasi debit puncak sebesar 4,515 $\mathrm{m}^{3} /$ detik, maka akurasi perhitungan metode rasional sebesar $60,9 \%$

$\begin{array}{ccc}\text { Mengacu } & \text { pada } & \text { pembahasan } \\ \text { sebelumnya } & \text { mengenai } & \text { penentuan }\end{array}$
karakteristik fisik DAS diperoleh ketelitian khususnya interpretasi penutup lahan dengan akurasi 85,7\%. Selain itu, didukung data dari SRTM dan hasil pengukuran lapangan untuk analisis karakteristik lingkungan fisik DAS mempengaruhi tingkat akurasi estimasi debit puncak. Berdasarkan hasil analisis perbandingan nilai debit puncak dan akurasi perhitungannya yang sudah diuraikan di atas, dapat dikemukakan bahwa perhitungan debit puncak rerata dengan menggunakan metode rasional memberikan hasil sebesar $16,07 \mathrm{~m}^{3} /$ detik, sedangakan perhitungan debit puncak dari hasil pengukuran lapangan menggunakan metode manning memberikan hasil sebesar 20,01 $\mathrm{m}^{3} /$ detik. Mengacu pada hasil tersebut maka ketelitian yang diperoleh adalah sebesar $80,31 \%$.

Penelitian sebelumnya pernah dilakukan oleh Gunawan (1991) berlokasi di DAS Bengawan Solo Hulu, yaitu menduga 
debit puncak dengan pendekatan karakteristik DAS menggunakan foto udara pankromatik hitam putih skala 1:10.000 tahun 1983 dan skala 1:50.000 tahun 1981 serta foto udara inframerah berwarna skala 1:30.000 tahun 1981. Hasil ketelitian yang diperoleh adalah sebesar $80 \%$. Kemudian Sudaryatno (2002) melakukan penelitian sejenis namun menggunakan data Landsat TM dengan membandingkan estimasi debit puncak menggunakan metode rasional dan hasil analisis hidrograf diperoleh ketelitian sebesar 95, 05\%. Berdasarkan hal tersebut dapat dikemukakan bahwa pemanfaatan data yang tepat serta pemilihan metode yang baik akan menentukan tingkat ketelitian estimasi debit puncak. Walaupun demikian, metode dan data penginderaan jauh tetap harus disesuaikan dengan karakteristik daerah penelitian.

\section{PENUTUP}

Berdasarkan hasil dan pembahasan, dapat kesimpulan, bahwa (1) citra Landsat 8 OLI komposit 563 (false Color) memperoleh akurasi sebesar $85,7 \%$ dari interpretasi penutup lahan, dan didukung data SRTM secara efektif dapat dimanfaatkan untuk ekstraksi data parameter karakteristik fisik DAS yang diperlukan untuk estimasi debit puncak. (2) perhitungan debit puncak rerata dengan menggunakan metode rasional memberikan hasil sebesar 16,07 $\mathrm{m}^{3} /$ detik, sedangkan perhitungan debit puncak dari hasil pengukuran lapangan menggunakan metode manning memberikan hasil sebesar $20,01 \mathrm{~m}^{3} /$ detik. Mengacu pada hasil tersebut maka ketelitian yang diperoleh adalah sebesar $80,31 \%$.

Saran yang dapat disampaikan adalah : (1) Citra satelit penginderaan jauh yang digunakan hendaknya memiliki kualitas yang baik dan disesuaikan dengan karakteristik daerah penelitian karena akan mempengaruhi hasil ekstraksi parameter yang diperlukan. (2) Diperlukan data curah hujan yang detail yaitu data intensitas curah hujan harian agar dapat melakukan analisis dengan baik dan tepat sehingga berpengaruh pada hasil estimasi debit puncak yang lebih baik.

\section{DAFTAR PUSTAKA}

Asdak, Chay. 2002. Hidrologi dan Pengelolaan Daerah Aliran Sungai. Yogyakarta: Gadjah Mada University Press.

Gunawan T. 1991. Penerapan Teknik Penginderaan Jauh Untuk Menduga Debit Puncak Menggunakan Karakteristik Lingkungan Fisik DAS (Studi Kasus Di Daerah Aliran Sungai Bangawan Solo Hulu, Jawa Tengah). Disertasi. Bogor : IPB.

Halengkara, Listumbinang. 2011. Analisis Kerusakan Lahan Untuk Pengelolaan DAS Melalui Integrasi Teknik Penginderaan Jauh Dan SIG (Kasus di DAS Blukar, Kab. Kendal Provinsi Jawa Tengah). Tesis. Yogyakarta: Fakultas Geografi UGM.

Kementerian Kehutanan RI, Ditjen Pengelolaan DAS dan Perhutanan Sosial, BPDAS Serayu Opak Progo. 2013. Pengertian Seputar DAS. Tersedia dalam http://bpdasserayuopakprogo.dephut. go.id/

Liliesand, T.M., W. Kiefer., Chipman, J.W. 2004. Remote Sensing And Image Interpretation (Fifth Edition). New York: John Wiley \& Sons, Inc.

Mather, P.M. 1987. Computer Processing Of Remote Sensed Data. London: Jhon Willey \& Sons. 
Sudaryatno. 2000. Penerapan Teknik Penginderaan Jauh dan Sistem Informasi Geografis Untuk Estimasi Debit Puncak Di Daerah Aliran Sungai Garang, Semarang, Jawa Tengah. Tesis. Yogyakarta : Pasca Sarjana UGM.

2002. Estimasi Debit Puncak di Daerah Aliran Sungai Garang Semarang dengan menggunakan Teknologi Inderaja dan Sistem
Informasi Geografis. Yogyakarta: Fakultas Geografi UGM.

Wibowo, Hendro. 2008. Transformasi NDVI Untuk Estimasi Nilai Koefisien Aliran (Kasus Aplikasi Citra Landsat ETM+ di DAS Citarum Hulu). Tesis. Yogyakarta: Fakultas Geografi UGM.

Yulius, Elma. 2014. Analisa Curah Hujan dalam Membuat Kurva Intensity Duration Frequency (IDF) pada Das Bekasi. Bekasi: Universitas Islam 45. 